\title{
Profil Personaliti dalam Kalangan Pensyarah UTM yang Cemerlang dalam Pengajaran dan Pembelajaran Berdasarkan Penilaian Pengajaran Pensyarah
}

\author{
Faizah Abd Ghani ${ }^{*}$ \\ ${ }^{a}$ Fakulti Pendidikan, Universiti Teknologi Malaysia, 81310 UTM Johor Bahru, Johor, Malaysia \\ *Corresponding author: faizah-ag@utm.my
}

\section{Article history}

Received : 1 November 2011

Received in revised form :19 April

2012

Accepted :15 December 2012

\begin{abstract}
This study aims to identify the personality profile among UTM lecturers who were excellent in teaching and learning based on the lecturers' teaching evaluation system (PPP) for semester 2 session 2007/2008 and semester 1 2008/2009. This study is corellational study and used the Big Five Personality Traits as framework research. A total of 52 lecturers had been selected using purposive sampling method. NEO-PIR inventory set by McCrae \& Costa (1992) and translated by Khairul Anwar (2000) had been used in this study. It shows a high level of reliability which demonstrated the alpha Cronbach value of .870 for Neuroticism, .804 for Extraversion, .790 for Openness to Experience, .682 for Agreeableness and .904 for Conscientiousness. Overall, the value of alpha Cronbach is .813. The data collected were analyzed using 'Statistical Packages for Social Sciences(SPSS v12 for windows). The result of the descriptive analysis showed that the majority of excellent lecturers have conscientiousness profile of personality ( mean=182.57), followed by agreeableness (mean=175.75) and extraversion (mean=160.019). The finding also showed that there was no significant between the profile of personality and achievement among the excellent lecturers.
\end{abstract}

Keywords:Personality profile; lecturer; excellent; teaching and learning; teaching evaluation

\begin{abstract}
Abstrak
Kajian ini bertujuan untuk mengkaji profil personaliti pensyarah UTM yang cemerlang dalam pengajaran dan pembelajaran berdasarkan Penilaian Pengajaran Pensyarah (PPP) bagi semester 2 sesi 2007/2008 dan semester 1 sesi 2008/2009. Kajian ini merupakan kajian korelasi dan menggunakan Teori Tret Personaliti Big Five sebagai kerangka kajian. Seramai 52 orang pensyarah cemerlang dalam PPP dilibatkan sebagai responden. Persampelan bertujuan digunakan dalam kajian ini dan Soal selidik NEO-PI-R oleh McCrae \& Costa (1992) yang diterjemahkan oleh Khairul Anwar (2000) digunakan sebagai instrumen kajian. Soal Selidik ini mempunyai nilai kebolehpercayaan yang baik berdasarkan nilai alpha Cronbach .870 bagi domain Neuroticism (N), .804 bagi domain Extraversion (E), .790 bagi domain Openness to Experience (O), .682 bagi domain Agreeableness (A), dan .904 bagi domain Conscientiousness (C). Nilai alpha Cronbach bagi keseluruhan item adalah .813. Data yang telah dikumpul dianalisis menggunakan 'Statistical Packages for Social Sciences' (SPSS) versi 12.0 for windows. Analisis deskriptif menunjukkan bahawa majoriti pensyarah yang cemerlang memiliki profil personaliti conscientiousness $(\mathrm{min}=182.57)$ diikuti dengan agreeableness $(\min =175.75)$ dan extraversion $(\min =160.019)$. Dapatan kajian menunjukkan tidak terdapat hubungan profil personaliti dengan pencapaian pensyarah yang cemerlang.
\end{abstract}

Kata kunci: Profil personaliti; pensyarah; cemerlang; pengajaran dan pembelajaran; penilaian pengajaran

\subsection{PENGENALAN}

Kualiti pengajaran telah menjadi salah satu agenda penting bagi universiti di dunia dan menjadi kritikal dalam menentukan kredibiliti sesebuah universiti (Johari, 2009). Peningkatan kualiti dan keberkesanan proses pengajaran dan pembelajaran telah dikenalpasti sebagai salah satu atribut utama dalam usaha menjadikan UTM sebagai sebuah universiti bertaraf dunia. Sehubungan itu, universiti telah pun bergerak aktif untuk meningkatkan kualiti dengan menggunakan garis panduan dan prosedur Amalan Jaminan Kualiti, Institusi Pengajian Tinggi Awam Malaysia (Polisi dan Kod Amalan P\&P, UTM).

Selaras dengan penubuhan Bahagian Jaminan Kualiti di Kementerian Pengajian Tinggi Malaysia, UTM juga 
memperkukuh dan menyelaras aktiviti-aktiviti jaminan kualiti agar usaha ini lebih cekap dan berkesan menerusi Pusat Pengajaran dan Pembelajaran (CTL) UTM. CTL ditubuhkan pada asasnya untuk melatih staf akademik UTM menguasai pengetahuan dan kemahiran berkaitan Pengajaran dan Pembelajaran (P\&P) di peringkat universiti bagi memenuhi misi menggalakkan kecemerlangan dan inovasi dalam pengajaran dan pembelajaran (Mohd Noor, 2007) bagi tujuan kualiti pengajaran dan pembelajaran. Hal ini sejajar dengan pandangan Nurhayati (2006) yang menekankan pendekatan kualiti dalam segenap aspek pendidikan perlu diberi tumpuan yang serius bagi mewujudkan sebuah institusi pendidikan yang efisyen dan efektif serta mencapai piawaian yang ditetapkan. Dalam usaha ini, peranan pensyarah perlu diberi perhatian yang serius kerana pensyarah yang berperanan sebagai staf akademik merupakan nadi kepada sesebuah universiti dan kewibawaan universiti amat bergantung kepada kewibawaan pensyarahnya.

Menurut Hativa (2001) pula, pengajaran yang baik bukanlah berdasarkan teknik pengajaran pengajar semata-mata, tetapi terhasil daripada identiti dan personaliti yang dicerminkan oleh pengajar terhadap pelajarnya. Golongan pensyarah perlulah terlebih dahulu berkeupayaan tinggi menjalankan tugas-tugas tersebut dengan sebaik mungkin bagi melahirkan pelajar yang cemerlang dalam akademik dan sahsiah (Salimah, 2002). Menurut Korthagen (2001), seseorang pensyarah bukan sahaja bergantung kepada ilmu pengetahuan yang diperolehinya tetapi personalitinya juga memainkan peranan penting dalam menjadikan seseorang itu pendidik seorang yang cemerlang dan efektif. Hal ini dikukuhkan lagi dengan pendapat Angelo (2002) yang mengatakan bahawa pendidik bertanggungjawab sebagai pendorong, pembimbing, penilai, serta pembentuk sahsiah kepada pelajarnya dan Salimah (2002) pula mengatakan bahawa profesionalisme pensyarah merangkumi beberapa aspek, dan antara yang paling penting adalah personaliti, keperihatinan, motivasi dan iltizam.

Toh (2003) pula berpandangan bahawa seorang pensyarah yang cemerlang mampu menghasilkan lebih ramai pelajar yang cemerlang dalam peperiksaaan. Beliau bersetuju bahawa kaedah pengajaran seorang pengajar akan memberi kesan kepada pencapaian akademik pelajar, samada secara positif atau negatif. Hal ini dikukuhkan dengan kajian yang dijalankan oleh Norliza Abu@Awang(2004) yang mendapati bahawa terdapat hubungan yang signifikan antara ciri-ciri personaliti pensyarah dan proses pengajaran. Dalam usaha membekalkan pendidikan berkualiti kepada pelajar, personaliti pensyarah memainkan agenda penting kerana pensyarah merupakan nadi kepada sesebuah universiti dan kewibawaan universiti amat bergantung kepada kewibawaan pensyarahnya (Tan Sri Prof. Dr. Mohd Zulkifli Mohd Ghazali,2007). Justeru, kajian ini dijalankan untuk mengenal pasti apakah ciri-ciri personaliti istimewa yang diperolehi sehingga menyebabkan mereka mampu mencapai keputusan yang sangat cemerlang di dalam PPP berbanding pensyarah-pensyarah lain di UTM? Sehubungan itu, kajian ini dijalankan untuk mengenal pasti apakah profil personaliti yang menyumbang kepada kecemerlangan seseorang pensyarah di UTM.

\subsection{OBJEKTIF KAJIAN}

Secara khususnya objektif kajian penyelidikan ini adalah seperti berikut:

1. Mengenal pasti profil tret personaliti dalam kalangan pensyarah yang cemerlang.

2. Mengenal pasti hubungan profil personaliti dengan pencapaian pensyarah yang cemerlang

\subsection{SOROTAN KAJIAN}

Terdapat beberapa kajian lepas yang bertekalan dengan pendapat yang mengatakan terdapat hubungan yang signifikan secara statistik yang positif antara gaya kepimpinan pensyarah dengan pencapaian akademik pelajar. Toh (2003) berpandangan bahawa seorang pensyarah yang cemerlang mampu menghasilkan lebih ramai pelajar yang cemerlang dalam peperiksaaan. Beliau bersetuju bahawa kaedah pengajaran seorang pengajar akan memberi kesan kepada pencapaian akademik pelajar, samada secara positif atau negatif.

Norliza Abu@ Awang (2004) telah menjalankan kajian untuk melihat perhubungan antara jenis ciri-ciri personaliti pensyarah dalam bidang teknik dan vokasional dengan proses pengajaran. Responden kajian ini terdiri daripada pensyarahpensyarah di Politeknik Ungku Omar. Ujian personaliti ini diukur menggunakan indikator Myers-Briggs (MBTI) sementara data yang dikumpulkan dianalisis menggunakan SPSS v11.0 for windows. Daripada kajian yang telah dijalankan, didapati14 daripada 16 jenis personaliti ditemui di dalam kajian ini.mendapati bahawa terdapat hubungan yang signifikan antara ciri-ciri personaliti pensyarah dan proses pengajaran. Dalam kajian tersebut, majoriti pensyarah memiliki jenis personaliti eskstrovert-sensing-thinking-judging (ESTJ) dan pencapaian akademik pelajar berada pada tahap sederhana.

Marzuki Ngah (2005) telah menjalankan kajian mengenai persepsi pelajar KPLI Maktab Perguruan Kuala Terengganu terhadap ciri-ciri personaliti atau tingkah laku pensyarah yang membantu meningkatkan pembelajaran mereka. Seramai 60 pelajar KPLI ambilan Januari dipilih secara rawak sebagai responden kajian. Hasil dapatan kajian tersebut mendapati bahawa ciri-ciri personaliti pensyarah yang paling membantu mereka ialah berakhlak baik dan peramah $(56.67 \%)$, memberi dorongan dan motivasi (53.33\%), tingkah laku kognitif yang baik (50\%), bertanggungjawab dan bersungguh sungguh (33.33\%), serta adil dan bertoleransi $(13.33 \%)$

Viren et al. (2007) telah menjalankan kajian tentang ciri-ciri personaliti pensyarah yang disukai daripada perspektif pelajar di tiga buah negara iaitu Britain, Malaysia,dan Amerika Syarikat. Kajian yang melibatkan 347 pelajar universiti di Britain, 235 pelajar universiti di Malaysia, dan 139 pelajar di Amerika Syarikat ini menyenaraikan 30 ciri-ciri yang disukai dan 30 ciriciri yang tidak disukai oleh pelajar universiti di ketiga-tiga negara tersebut. Ciri-ciri personaliti berkenaan kemudiannya dikodkan mengikut taksonomi personaliti Big Five. Dapatan kajian menunjukkan majoriti responden cenderung untuk memilih tret personaliti Conscientiousness Openness to Experience dan Agreeableness.

\subsection{METODOLOGI KAJIAN}

Kajian yang dijalankan ini adalah merupakan kajian kuantitatif sepenuhnya. Ini disebabkan kajian hanya melibatkan data yang berkaitan dengan penganalisaan berkaitan dengan nombor (Babbie, 2008). Selain itu, kajian ini merupakan sebuah kajian korelasi kerana melibatkan pengukuran darjah hubungan atau perkaitan antara dua pemboleh ubah (McBurney dan White, 2000).

Kajian ini dijalankan di sepuluh buah fakulti yang terdapat di UTM Skudai iaitu Fakulti Kejuruteraan Awam (FKA), Fakulti Kejuruteraan Elektrik (FKE), Fakulti Kejuruteraan Mekanikal (FKM), Fakulti Kejuruteraan Kimia dan Kejuruteraan Sumber Asli (FKKKSA), Fakulti Sains (FS), Fakulti Sains Komputer dan Sistem Maklumat(FSKSM), Fakulti Pengurusan dan Pembangunan Sumber Manusia (FPPSM), Fakulti Pendidikan 
(FP), Fakulti Tamadun Islam (FTI), dan Fakulti Biosains dan Biokejuruteraan (FBB).

\subsection{Populasi dan Sampel Kajian}

Populasi kajian terdiri daripada pensyarah-pensyarah yang mendapat keputusan 5\% tertinggi dalam Penilaian Pengajaran Pensyarah (PPP) bagi semester 2 sesi2007/2008 dan sesi 1 2008/2009. Penyelidik memfokuskan pensyarah-pensyarah yang mendapat $5 \%$ tertinggi kerana mereka merupakan pensyarah yang mendapat ranking terbaik di UTM. Seramai 52 orang pensyarah daripada 10 buah fakulti di UTM yang terpilih dengan menggunakan kaedah persampelan bertujuan.

\subsection{Instrumen Kajian}

Pengkaji menggunakan kaedah soal selidik untuk mengkaji profil personaliti pensyarah yang cemerlang di UTM. Soal selidik digunakan kerana soal selidik merupakan alat pengukuran yang sesuai digunakan dalam penyelidikan pendidikan, dan ia lebih praktikal berbanding kaedah-kaedah lain kerana penganalisisan data dapat dijalankan dengan lebih tepat dan berkesan (Fraenkel \& Wallen, 2008).

Soal selidik ini terbahagi kepada dua bahagian iaitu Bahagian A dan Bahagian B.

\subsubsection{Bahagian A : Latar Belakang Demografi}

Bahagian A merupakan bahagian yang meminta responden untuk mengisi maklumat latar belakang diri responden yang terdiri dari segi jantina, umur, bangsa, taraf perkahwinan, tempoh perkhidmatan, jawatan, taraf jawatan. kelulusan akademik dan pencapaian pengajaran.

\subsubsection{Bahagian B : Inventori Personaliti NEO-PI-R}

Soal selidik yang digunakan di dalam kajian ini ialah set inventori personaliti Neuroticism Extraversion Openness (NEO) Personality Inventory (PI)-Revised (R) yang telah dibina oleh Costa \& McCrae (1992) dan telah diterjemah ke dalam Bahasa Malaysia oleh Khairul Anwar (2000). Khairul anwar et al. (2000) telah menjalankan kajian menggunakan set inventori NEO-PI-R untuk mengkaji personaliti masyarakat Melayu menggunakan pendekatan Big Five. Dapatan kajian beliau jelas menunjukkan bahawa set inventori ini sesuai digunakan pada masyarakat di Malaysia berdasarkan nilai kebolehpercayaannya yang tinggi.

Menurut McCrae \& Costa, $(1987,1997)$ di dalam Khairul Anwar (2000), hampir kesemua kajian-kajian lepas menunjukkan nilai pemboleh ubah yang lebih tinggi daripada .90 bagi kelimalima domain berkenaan. Merujuk kepada analisis kebolehpercayaan bagi kelima-lima domain di dalam kajian tersebut (N=62), pekali Alpha Cronbach yang didapati daripada kajian adalah adalah 0.92 bagi domain Neuroticism $(\mathrm{N}), 0.87$ bagi domain Extraversion (E), 0.60 bagi domain Openness to Experience (O), 0.81 bagi domain Agreeableness (A), dan 0.88 bagi domain Conscientiousness (C). Oleh kerana soal selidik ini mempunyai kebolehpercayaan yang tinggi, ia dianggap mempunyai kesilapan relatif yang minimum, dan mengukur apa yang sepatutnya diukur (Goodwin, 2008).

Set inventori ini mengandungi 240 item di dalam Bahagian B ini memberi fokus kepada lima domain personaliti, iaitu Neutroticism (N), Extraversion (E),Openness to experience $(O)$, Agreeableness (A), dan Conscientiousness (C) Setiap domain mempunyai enam faset, dan setiap faset pula mempunyai lapan item. Item-item tersebut diukur oleh Skala Likert lima mata yang berskala daripada"Sangat Tidak Setuju" sehingga "Sangat Setuju."

\subsection{Analisis Data}

Dapatan data yang diperolehi daripada kajian dianalisis dengan menggunakan kaedah analisis deskriptif dan inferensi. Analisis deskriptif berbentuk peratus, min dan sisihan piawai telah digunakan untuk mengukur objektif pertama manakala analisis inferensi dalam bentuk Ujian korelasi Pearson R digunakan bagi mengukur objektif kedua.

\subsection{DAPATAN KAJIAN}

Perbincangan dalam bahagian ini merangkumi analisis data deskriptif dan inferensi terhadap 52 orang responden yang mencapai peratus tertinggi dalam pengajaran. Analisis dilakukan dengan menggunakan perisian Statistical Packeges for Sosial Science (SPSS) versi 13.0.

\subsection{Analisis Deskriptif Jantina Responden}

Jadual 4.1 menunjukkan taburan bilangan responden dan pemeratusannya dari segi jantina. Dapatan menunjukkan bilangan responden lelaki melebihi bilangan responden perempuan. Bilangan responden perempuan sebanyak $54.9 \%(n=28)$ manakala bilangan responden perempuan adalah sebanyak $45.1 \%(n=23)$.

Jadual 4.1 Taburan kekerapan dan peratus mengikut jantina

\begin{tabular}{ccc}
\hline Jantina & Kekerapan $(\boldsymbol{f})$ & Peratus (\%) \\
\hline Lelaki & 28 & 54.9 \\
Perempuan & 23 & 45.1 \\
Jumlah & 52 & 100 \\
\hline
\end{tabular}

\subsection{Analisis Deskriptif Umur Responden}

Jadual 4.2 menunjukkan taburan kekerapan bilangan responden dan pemeratusannya dari segi umur. Dapatan menunjukkan responden berumur 41 hingga 50 tahun mendominasi kajian ini dengan peratusan tertinggi sebanyak $53.8 \% \quad(n=28)$, diikuti dengan responden berumur lebih daripada 50 tahun iaitu sebanyak $23.1 \%(n=12), 31$ hingga 40 tahun sebanyak $15.4 \%(n=8)$ dan kurang daripada 30 tahun sebanyak $7.7 \%(n=4)$.

Jadual 4.2 Taburan kekerapan dan peratus mengikut umur

\begin{tabular}{ccc}
\hline Umur & Kekerapan $(\boldsymbol{f})$ & Peratus (\%) \\
\hline Kurang daripada 30 & & \\
tahun & 4 & 7.7 \\
31 hingga 40 tahun & 8 & 15.4 \\
41 hingga 50 tahun & 28 & 53.8 \\
Lebih daripada 50 & & \\
tahun & 12 & 23.1 \\
Jumlah & 52 & 100 \\
\hline
\end{tabular}

\subsection{Analisis Deskriptif Bangsa Responden}

Jadual 4.3 menunjukkan taburan kekerapan bilangan responden dan pemeratusannya dari segi bangsa. Dapatan menunjukkan responden Melayu mendominasi kajian ini dengan peratusan tertinggi sebanyak $82.7 \% \quad(n=43)$, diikuti dengan responden berbangsa Cina iaitu sebanyak $7.7 \%(n=4)$, bangsa India iaitu $5.8 \%(\mathrm{n}=2)$ dan lain-lain bangsa iaitu sebanyak $3.8 \%(\mathrm{n}=2)$. 
Jadual 4.3 Taburan kekerapan dan peratus mengikut umur

\begin{tabular}{lll}
\hline \multicolumn{1}{r}{ Bangsa } & \multicolumn{1}{c}{ Kekerapan $(\boldsymbol{f})$} & Peratus $(\%)$ \\
\hline Melayu & 43 & 82.7 \\
Cina & 4 & 7.7 \\
India & 3 & 5.8 \\
Lain-lain & 2 & 3.8 \\
Jumlah & 52 & 100 \\
\hline
\end{tabular}

\subsection{Analisis Deskriptif Taraf Perkahwinan Responden}

Jadual 4.4 menunjukkan taburan bilangan responden dan pemeratusannya dari segi status perkahwinan. Dapatan menunjukkan bilangan responden yang berkahwin merupakan bilangan yang paling ramai iaitu sebanyak $80.8 \% \quad(n=42)$, manakala bujang sebanyak $15.4 \%(\mathrm{n}=96)$ dan status lain-lain pula sebanyak .9\% $(\mathrm{n}=2)$.

Jadual 4.4 Taburan kekerapan dan peratus mengikut status perkahwinan

\begin{tabular}{lll}
\hline Taraf Perkahwinan & Kekerapan $(\boldsymbol{f})$ & Peratus $(\boldsymbol{\%})$ \\
\hline Bujang & 8 & 15.4 \\
Berkahwin & 42 & 80.8 \\
Duda/Janda & 2 & 3.8 \\
Jumlah & 52 & 100 \\
\hline
\end{tabular}

\subsection{Analisis Deskriptif Tempoh Berkhidmat di UTM}

Jadual 4.5 menunjukkan taburan bilangan responden dan pemeratusan dari segi tempoh pengalaman berkhidmat di UTM. Dapatan menunjukkan responden yang berkhidmat 21 tahun ke atas merupakan responden yang paling ramai iaitu sebanyak $34.6 \%(\mathrm{n}=18)$, diikuti dengan responden yang berkhidmat selama 10 hingga 14 tahun $(\mathrm{n}=12), 15$ hingga 20 tahun sebanyak $19.2 \%$ $(\mathrm{n}=10), 5$ hingga 9 tahun sebanyak $15.4 \%(\mathrm{n}=8)$ dan kurang dari 5 tahun sebanyak $7.7 \%$. sebanyak $4.8 \%(n=18)$.

Jadual 4.5 Taburan kekerapan dan peratus tempoh khidmat di UTM

\begin{tabular}{llll}
\hline \multicolumn{2}{l}{ Tempoh Khidmat } & Kekerapan $(\boldsymbol{f})$ & Peratus (\%) \\
\hline Kurang dari & 5 & & \\
tahun & 4 & 7.7 \\
5 hingga 9 tahun & 8 & 15.4 \\
10 hingga 14 tahun & 12 & 23.1 \\
15 hingga 20 tahun & 10 & 19.2 \\
21 tahun ke atas & 18 & 34.6 \\
Jumlah & 52 & 100 \\
\hline
\end{tabular}

\subsection{Analisis Deskriptif Jawatan Responden}

Jadual 4.6 menunjukkan taburan bilangan responden dan pemeratusannya dari segi jawatan. Dapatan menunjukkan responden yang paling ramai terlibat di dalam kajian ini ialah yang berjawatan pensyarah DS 45 iaitu sebanyak 36.5\% $(n=19)$, diikuti oleh responden yang berjawatan pensyarah kanan iaitu sebanyak $28.8 \% \quad(n=15)$, seterusnya profesor madya iaitu sebanyak $21.1 \%(\mathrm{n}=11)$ dan guru bahasa dan profesor adalah $3.8 \%(\mathrm{n}=2)$.
Jadual 4.6 : Taburan kekerapan dan peratus mengikut jawatan

\begin{tabular}{|c|c|c|}
\hline Jawatan & Kekerapan $(f)$ & Peratus (\%) \\
\hline Guru bahasa & 2 & 3.8 \\
\hline $\begin{array}{l}\text { Pembantu Pensyarah } \\
\text { (tutor) }\end{array}$ & 3 & 5.8 \\
\hline Pensyaran DS 45 & 19 & 36.5 \\
\hline $\begin{array}{l}\text { Pensyarah Kanan DS } \\
51 / 52\end{array}$ & 15 & 28.8 \\
\hline Professor Madya & 11 & 21.2 \\
\hline Professor & 2 & 3.8 \\
\hline Jumlah & 52 & 100 \\
\hline
\end{tabular}

\subsection{Analisis Deskriptif Taraf Jawatan}

Jadual 4.7 menunjukkan taburan bilangan responden dan pemeratusannya dari segi taraf jawatan. Dapatan menunjukkan responden yang berjawatan tetap mendominasi kajian ini dengan peratusan tertinggi sebanyak $88.5 \% \quad(n=46)$, diikuti dengan responden yang berjawatan kontrak kelulusan iaitu sebanyak $7.7 \% \%(\mathrm{n}=4)$, manakala responden yang berjawatan kontrak dan lain-lain adalah sebanyak $1.9 \%(\mathrm{n}=1)$.

Jadual 4.7 Taburan kekerapan dan peratus mengikut taraf jawatan

\begin{tabular}{lll}
\hline Taraf Jawatan & Kekerapan $(f)$ & Peratus ( \% ) \\
\hline Sementara & 1 & 1.9 \\
Tetap & 46 & 88.5 \\
Kontrak & 4 & 7.7 \\
Lain-lain & 1 & $1 ; 9$ \\
Jumlah & 52 & 100 \\
\hline
\end{tabular}

5.8 Analisis Deskriptif Kelulusan Akademik Tertinggi Responden

Jadual 4.8 menunjukkan taburan bilangan responden dan pemeratusannya dari segi kelulusan akademik tertinggi. Dapatan menunjukkan responden yang mempumyai kelulusan akademik tertinggi peringkat ijazah doktor falsafah mendominasi kajian ini dengan peratusan tertinggi sebanyak $50.0 \% \quad(n=26)$, diikuti dengan kelulusan sarjana iaitu sebanyak $46.2 \%(n=24)$, manakala hanya $3.8 \%(n=2)$ yang berkelulusan sarjana muda.

Jadual 4.8 Taburan kekerapan dan peratus mengikut kelulusan akademik tertinggi

\begin{tabular}{lll}
\hline Kelulusan Akademik & Kekerapan $(\boldsymbol{f})$ & Peratus ( \% ) \\
\hline Sarjana Muda & 2 & 3.8 \\
Sarjana & 24 & 46.2 \\
Doktor Falsafah & 26 & 50.0 \\
Jumlah & 52 & 100 \\
\hline
\end{tabular}

\subsection{Analisis Deskriptif Fakulti}

Jadual 4.9 menunjukkan taburan bilangan responden dan pemeratusannya dari aspek fakulti. Dapatan kajian menunjukkan bilangan responden yang mengajar di Fakulti Pendidikan adalah 
mendominasi pencapaian $5 \%$ tertinggi iaitu 30.8\% (n=16), diikuti dengan fakulti FPPSM iaitu sebanyak $19.2 \%(n=10)$ dan FKA iaitu sebanyak $11.5 \%(\mathrm{n}=6)$, manakala FKE dan FTI adalah sebanyak $5.8 \% \quad(\mathrm{n}=2)$, FKM, FSKSM dan FKKSA adalah sebanyak 3.8\% $(n=2)$ dan FBB adalah sebanyak 1.9\% $(n=1)$.

Jadual 4.9 Taburan kekerapan dan peratus mengikut fakulti

\begin{tabular}{lll}
\hline Fakulti & Kekerapan $(\boldsymbol{f})$ & Peratus $(\%)$ \\
\hline FPPSM & 10 & 19.2 \\
FS & 7 & 13.5 \\
FP & 16 & 30.8 \\
FKA & 6 & 11.5 \\
FKE & 3 & 5.8 \\
FKM & 2 & 3.8 \\
FTI & 3 & 5.8 \\
FSKSM & 2 & 3.8 \\
FKKSA & 2 & 3.8 \\
FBB & 1 & 1.9 \\
Jumlah & 52 & 100 \\
\hline
\end{tabular}

\subsection{Analisis Deskriptif Profil Personaliti}

Jadual 4.10 menunjukkan analisis min profil personaliti pensyarah cemerlang di UTM. Dapatan kajian menunjukkan bahawa profil conscientiousness yang tinggi dengan $\min =182.57$ mendominasi responden dan diikuti dengan profil agreeableness $(\min =175.75)$, extraversion $\quad(\min =160.01, \quad$ openness $\quad(\min =156.38) \quad$ dan neuroticism $(\mathrm{min}=124.09)$.

Jadual 4.10 Nilai min bagi setiap domain personaliti responden

\begin{tabular}{llll}
\hline Bil & Domain & Nilai Min & Pengkelasan \\
\hline 1. & Neuroticism & 124.096 & sederhana \\
2. & Extraversion & 160.019 & sederhana \\
3. & Openness & 156.38 & sederhana \\
4. & Agreeableness & 175.75 & sederhana \\
5. & Conscientiousness & 182.577 & tinggi
\end{tabular}

\subsection{Analisis Inferensi}

5.11.1 Ho1: Tidak terdapat hubungan yang signifikan antara profil personaliti neuroticism dengan faktor pencapaian dalam kalangan pensyarah cemerlang.

Jadual 4.11 menunjukkan keputusan kajian bagi hubungan antara personaliti neuroticism dengan faktor pencapaian. Analisis korelasi Pearson menunjukkan bahawa nilai pekali korelasi, $r$ bagi kedua-dua pemboleh ubah tersebut ialah .278 Ini menunjukkan satu hubungan positif yang sangat lemah wujud antara kedua-dua pemboleh ubah. Bagi nilai signifikan pula, $p=0.153$ adalah lebih besar daripada aras signifikan yang ditetapkan iaitu 0.05 . Oleh yang demikian, tidak terdapat hubungan yang signifikan di antara personaliti jenis neuroticism dengan pencapaian prestasi pensyarah cemerlang UTM. Oleh itu, hipotesis nol pertama gagal ditolak.
Jadual 4.11 Analisis hubungan profil personaliti neuroticism dengan faktor pencapaian

\begin{tabular}{lll}
\hline $\begin{array}{l}\text { Hubungan Pemboleh } \\
\text { ubah }\end{array}$ & $\mathrm{R}$ & $\mathrm{P}$ \\
\hline $\begin{array}{l}\text { Personaliti } \\
\text { Neuroticism dengan }\end{array}$ & .278 & .153 \\
faktor pencapaian & & \\
* Signifikan pada aras .05 & &
\end{tabular}

5.11.2 Ho2: Tidak terdapat hubungan yang signifikan antara profil personaliti Extraversion dengan faktor pencapaian dalam kalangan pensyarah cemerlang

Jadual 4.12 menunjukkan keputusan kajian bagi hubungan antara personaliti extraversion dengan faktor pencapaian. Analisis korelasi Pearson menunjukkan bahawa nilai pekali korelasi, $\mathrm{r}$ bagi kedua-dua pemboleh ubah tersebut ialah -.136. Ini menunjukkan satu hubungan negatif yang sangat lemah wujud antara kedua-dua pemboleh ubah. Bagi nilai signifikan pula, $p=0.337$ adalah lebih besar daripada aras signifikan yang ditetapkan iaitu 0.05 . Oleh yang demikian, tidak terdapat hubungan yang signifikan di antara personaliti jenis extraversion dengan pencapaian prestasi pensyarah cemerlang UTM. Oleh itu, hipotesis nol kedua gagal ditolak.

Jadual 4.12 Analisis hubungan profil personaliti extraversion dengan faktor pencapaian

\begin{tabular}{lll}
\hline $\begin{array}{l}\text { Hubungan Pemboleh } \\
\text { ubah }\end{array}$ & $\mathrm{R}$ & $\mathrm{P}$ \\
\hline Personaliti & -.136 & 0.337 \\
$\begin{array}{l}\text { Extraversion dengan } \\
\text { faktor pencapaian }\end{array}$ & & \\
*Signifikan pada aras .05 & &
\end{tabular}

5.11.3 Ho3: Tidak terdapat hubungan yang signifikan antara profil personaliti Openness dengan faktor pencapaian dalam kalangan pensyarah cemerlang

Jadual 4.13 menunjukkan keputusan kajian bagi hubungan antara personaliti openess dengan faktor pencapaian. Analisis korelasi Pearson menunjukkan bahawa nilai pekali korelarai, $r$ bagi keduadua pemboleh ubah tersebut ialah -.105 Ini menunjukkan satu hubungan negatif yang sangat lemah wujud antara kedua-dua pemboleh ubah. Bagi nilai signifikan pula, $p=0.461$ adalah lebih besar daripada aras signifikan yang ditetapkan iaitu 0.05. Oleh yang demikian, tidak terdapat hubungan yang signifikan di antara personaliti jenis Openess dengan pencapaian prestasi pensyarah cemerlang UTM. Oleh itu, hipotesis nol ketiga gagal ditolak.

Jadual 4.13 Analisis hubungan profil personaliti Openess dengan faktor pencapaian

\begin{tabular}{lrll}
\hline $\begin{array}{l}\text { Hubungan } \\
\text { ubah }\end{array}$ & Pemboleh & $\mathrm{R}$ & $\mathrm{P}$ \\
\hline $\begin{array}{l}\text { Personaliti } \\
\text { dengan }\end{array}$ & $\begin{array}{r}\text { Openess } \\
\text { faktor }\end{array}$ & -.105 & .461 \\
pencapaian & & \\
Signifikan pada aras .05 & & \\
\hline
\end{tabular}


5.11.4 Ho4: Tidak terdapat hubungan yang signifikan antara profil personaliti Agreeableness dengan faktor pencapaian dalam kalangan pensyarah cemerlang

Jadual 4.14 menunjukkan keputusan kajian bagi hubungan antara personaliti agreeableness dengan faktor pencapaian. Analisis korelasi Pearson menunjukkan bahawa nilai pekali korelasi, $r$ bagi kedua-dua pemboleh ubah tersebut ialah -.077. Ini menunjukkan satu hubungan negatif yang sangat lemah wujud antara kedua-dua pemboleh ubah. Bagi nilai signifikan pula, $\mathrm{p}=0.587$ adalah lebih besar daripada aras signifikan yang ditetapkan iaitu 0.05 . Oleh yang demikian, tidak terdapat hubungan yang signifikan di antara personaliti jenis agreeableness dengan pencapaian prestasi pensyarah cemerlang UTM. Oleh itu, hipotesis nol keempat gagal ditolak.

Jadual 4.14 Analisis hubungan profil personaliti Agreeableness dengan faktor pencapaian

\begin{tabular}{lll}
\hline $\begin{array}{l}\text { Hubungan Pemboleh } \\
\text { ubah }\end{array}$ & $\mathrm{R}$ & $\mathrm{P}$ \\
\hline $\begin{array}{l}\text { Personaliti } \\
\text { Agreeableness dengan } \\
\text { faktor pencapaian }\end{array}$ & -.077 & .587 \\
Signifikan pada aras .05 & & \\
\hline
\end{tabular}

5.11.5 Ho5: Tidak terdapat hubungan yang signifikan antara profil personaliti Conscientiousness dengan faktor pencapaian dalam kalangan guru sekolah menengah di negeri Johor.

Jadual 4.14 menunjukkan keputusan kajian bagi hubungan antara personaliti Conscientiousness dengan faktor pencapaian. Analisis korelasi Pearson menunjukkan bahawa nilai pekali korelasi, $\mathrm{r}$ bagi kedua-dua pemboleh ubah tersebut ialah -.061. Ini menunjukkan satu hubungan negatif yang sangat lemah wujud antara kedua-dua pemboleh ubah. Bagi nilai signifikan pula, $\mathrm{p}=0.665$ adalah lebih besar daripada aras signifikan yang ditetapkan iaitu 0.05. Oleh yang demikian, tidak terdapat hubungan yang signifikan di antara personaliti jenis conscientiousness dengan pencapaian prestasi pensyarah cemerlang UTM. Oleh itu, hipotesis nol kelima gagal ditolak.

Jadual 4.14 Analisis hubungan profil personaliti Conscientiousness dengan faktor pencapaian

\begin{tabular}{lll}
\hline $\begin{array}{l}\text { Hubungan Pemboleh } \\
\text { ubah }\end{array}$ & $\mathrm{R}$ & $\mathrm{P}$ \\
\hline $\begin{array}{l}\text { Personaliti } \\
\begin{array}{l}\text { consientiousness } \\
\text { dengan faktor }\end{array}\end{array}$ & -.061 & 0.665 \\
pencapaian & & \\
Signifikan pada aras .05 & &
\end{tabular}

\subsection{KESIMPULAN}

Secara keseluruhan dapatan kajian menunjukkan profil conscientiousness merupakan min yang tertinggi dalam kalangan pensyarah yang cemerlang di Universiti Teknologi Malaysia. Dapatan kajian juga menunjukkan bahawa tahap conscientiousness dalam kalangan pensyarah berada di tahap yang tinggi. Hal ini menunjukkan bahawa pensyarah yang cemerlang ini mempunyai disiplin diri yang kuat, menumpukan perhatian dan mengikut perancangan yang telah diatur dengan baik selain daripada bersikap cermat, menepati masa, boleh dipercayai dan bertanggungjawab. Menurut Hogan et al. (1996), conscientiousness merupakan aspek yang paling penting dalam keikhlasan. Hal ini bertekalan dengan pandangan Howard P.J., \& Howard J.M (2001) mengatakan golongan yang mendapat skor tinggi bagi domain conscientiousness bersifat sangat teratur, bercita-cita tinggi dan mementingkan kesempurnaan dalam melaksanakan tugas.

Dapatan kajian ini menunjukkan bahawa pensyarah yang cemerlang sentiasa mempunyai persediaan yang cukup sebelum melaksanakan tugas, komitted terhadap tugas dan bersungguhsungguh. Hal ini dikukuhkan dengan pandangan Noran Fauziah \& Ahmad (2002) yang menyatakan bahawa proses pengajaran memerlukan pensyarah untuk membuat persediaan yang rapi dan teliti supaya pensyarah akan berasa yakin dalam penyampaian kuliahnya. Selain itu menurut Leonard \& Karen (1996) pendidik yang cemerlang memiliki komitmen yang tinggi terhadap tugas.

Dapatan kajian juga menunjukkan tidak terdapat hubungan yang signifikan di antara profil personaliti pensyarah dengan faktor pencapaian. Hal ini menunjukkan bahawa personaliti pensyarah tidak mempengaruhi prestasi pencapaian. Ini menunjukkan prestasi pencapaian bukan matlamat utama pensyarah, namun kualiti diri yang ditekankan oleh pensyarah itu sendiri. Hal ini dibuktikan dengan dapatan kajian yang menunjukkan kualiti diri pensyarah yang berpersonaliti conscientiousness mempunyai tret yang bersungguh-sungguh, dipercayai dan bersifat wajar serta realistik. Dalam erti kata yang lain, personaliti pensyarah yang berdimensi Conscientiousness yang tinggi amat berhati-hati semasa membuat sebarang keputusan, bertindak secara rasional, boleh dipercayai, sanggup bekerja keras untuk sesuatu tugasan, menepati masa, kemas dari segai kerjanya dan peribadi, berdisiplin serta bercita-cita tinggi serta kehidupan yang teratur.

\subsection{Cadangan Tindakan Kajian}

Berdasarkan dapatan yang telah diperolehi, maka disarankan beberapa cadangan bagi dimanafaatkan oleh semua pihak. Berikut adalah antara cadangan yang dikemukakan:

1. Pihak Universiti seharusnya menjalankan langkah-langkah tertentu untuk meningkatkan prestasi pencapaian cemerlang dalam pengajaran dan pembelajaran dalam kalangan pensyarah. Hal ini kerana pencapaian 5\% tertinggi dalam kalangan pensyarah di UTM masih dalam keadaan yang tidak memberangsangkan. Insentif dalam bentuk bonus, ganjaran, hadiah dan nilai mata kredit juga boleh diimplimentasikan dan direalisasikan agar peningkatan $\mathrm{P}$ \& $\mathrm{P}$ dalam kalangan pensyarah benar-benar berkualiti. Hal ini secara tidak langsung boleh mengharumkan nama dan imej UTM.

2. Dapatan kajian ini juga menunjukkan bahawa terdapat personaliti pensyarah yang cemerlang mempunyai tret neuroticism (min yang sederhana). Hal ini boleh memberi implikasi yang negatif kerana personaliti pensyarah yang mempunyai tret ini lebih cenderung untuk bertindak di luar kawalan, beremosi, tertekan, burn out dan boleh memberi kesan dalam menggapai matlamat UTM ke arah Universiti Bertaraf Dunia. Sehubungan itu, pihak UTM boleh merencanakan dan menjalankan kursus-kursus atau bengkelbengkel yang bersesuaian bagi mengatasi personaliti pensyarah yang neuroticsm.

3. Pihak Universiti perlu mengenal pasti aspek personaliti dalam pemilihan jawatan pensyarah agar pensyarah yang ada benar-benar layak dan berkualiti serta berketrampilan dan mempunyai sahsiah yang baik dalam membentuk modal 
insan (pelajar) selain mengatur strategi pengajaran dan pembelajaran yang lebih kreatif dan dinamik dalam kalangan pensyarah.

4. Sistem mentoring boleh juga diaplikasikan dalam $P$ \& $P$ terutama kepada tenaga pensyarah yang muda yang tiada pengalaman $\mathrm{P} \& \mathrm{P}$. Sehubungan itu, pensyarah yang mempunyai pencapaian yang cemerlang dalam P \& P dan berpesonaliti yang baik boleh dijadikan mentor untuk berkongsi pengalaman kepada pensyarah yang baru. Hal ini boleh meningkatkan semangat kerjasama dan toleransi serta memupuk budaya tolong menolong dalam memajukan P \& P di UTM.

5. Menerusi kajian ini, pihak pensyarah boleh memanfaatkan dapatan kajian ini untuk menilai kembali personaliti diri dalam usaha memperbaiki diri ke arah yang lebih cemerlang. Hal ini perlu kerana pensyarah merupakan model kepada pelajar dalam usaha memartabatkan UTM sebagai universiti terbilang di mata dunia.

\subsection{Cadangan Kajian Lanjutan}

Berdasarkan hasil dapatan ini, penyelidik ingin mengemukakan beberapa cadangan kepada penyelidik-penyelidik yang lain untuk membuat kajian lanjutan berdasarkan aspek yang telah dibincangkan dalam kajian ini. Ia merangkumi aspek:

Kajian ini hanya dijalankan ke atas pensyarah-pensyarah yang mendapat $5 \%$ tertinggi pencapaian dalam penilaian P \& P di UTM. Justeru itu dapatan kajian ini tidak boleh digeneralisasikan kepada seluruh pensyarah di UTM. Kajian ini akan menjadi lebih bermakna, jika seluruh pensyarah di UTM dilibatkan sebagai responden.

Kajian ini hanya terbatas kepada kajian yang mengukur hubungan antara profil personaliti pensyarah dengan faktor pencapaian. Sehubungan itu, kajian yang mendalam dengan melihat perbezaan antara jantina, tempoh khidmat, jawatan, taraf jawatan, akademik dan fakulti boleh dilakukan oleh penyelidik akan datang.

\section{Rujukan}

Kadir Hj. Ismail. 1974. Prinsip-Prinsip Pendidikan. Kota Bharu: Pustaka Aman Press.

Harris, Muijs, D. 2005. School Improvement through Teacher Leadership. Open University Press.

Abdullah Sani Yahaya, Abd. Rashid Mohamad, Abd. Ghani Abdullah. 2007. Guru Sebagai Pemimpin. Kuala Lumpur: PTS Profesional.

Abu Hassan Kassim. \& Meor Ibrahim Kamaruddin. 1995. Penyelia Dan Penyeliaan Pengajaran Guru Pelatih: Perancangan \& Penyampaian Rancangan Pengajaran. Skudai: Penerbit UTM.

Alauddin Sidal. 2002. Dorongan Dalam Organisasi. Kuala Lumpur: INTAN.

Allen, B. P. 2002. Personalities Theories: Development, Growth, and Diversity. Boston: Allyn and Bacon.

Angelo, T. A. 2002. Teaching Goals, Assessment, Academic Freedom and Higher Learning: Essay on Teaching Learning. Dalam Essay on Teaching Excellence: Toward the Best in the Academy. Muat turun pada 29 Julai 2008. http://www.ucet.ufl.edu/ProgramServices/htm

Arham Abdullah \& Baharin Mesir \& Ahmad Muhaimin. 2006. Faktor-faktor Yang Menyumbang Kepada Kecemerlangan Akademik Pelajar Di Universiti Teknologi Malaysia. Universiti Teknologi Malaysia: Kajian Pendidikan.

Ary, D., Jacobs, L. C \& Razavieh, A. 1985. Introduction to Research in Education. 3rd edition. New York: Holt, Rinehart and Winston.

Atan Long. 1998. Pedagogi: Kaedah Am Mengajar. Kuala Lumpur: Fajar Bakti.

Azizi Yahaya. 2006. Menguasai Penyelidikan dalam Pendidikan: Teori \& Interprestasi Data. Kuala Lumpur: PTS Profesional.
Babbie, E. 2008. The Basics of Social Research. 4th ed. Belmont: Thomson Wadsworth.

Batiah Mahadi. 2002. Determinants of Teaching Quality and Factors Influencing Students' Learning in the Case of Management Students in UTM's Diploma Programme (PPD). Universiti Teknologi Malaysia: Tesis Sarjana.

Boyle, G. J., \& Saklofske, D. H. (Eds). 2004. The Psychology of the Individual Differences. Vol. 4. London: Sage Publications Ltd.

Barrick, M. R., \& Mount, M. K. 1991. The Big Five Personality Dimensions and The Job Performance: A Met-analysis. Personnel Psychology. 44: 126.

Clark, M. D. 1997. Teacher Responses to Learning Disabilities: A Test to Attributional Principles. Journals of Learning Disabilities. 30(1): 69-79.

Cooper, C. L., \& Payne, R. 1998. Causes, Coping, and Consequences of Stress At Work. New York: John Wiley \& Sons. Inc.

Datuk Dr. Syed Othman Alhabshi \& Hasnan Hakim. 2001. Dasar dan Perlaksanaan Sistem Pendidikan Kebangsaan. Kertas Kerja yang dibentangkan di Kongres Pendidikan Melayu di Dewan Merdeka, Pusat Dagangan Dunia Putra (PWTC), Kuala Lumpur.

Digman, J. M. 1990. Personality Structure: Emergence of The Five Factor Model. Annual Review of Psychology. 4: 417-446.

Erine Britian. 2005. Personaliti Guru dan Hubungannya Dengan Prestasi Akademik Pelajar: Satu Kajian di Sekolah Menengah Sains Kuching, Kuching, Sarawak. Universiti Teknologi Malaysia: Tesis Sarjana Muda.

Fitzmaurice, M. 2008. Voices from within: Teaching in Higher Education as a Moral Practice. Teaching in Higher Education. 13(3): 341-352.

Goodwin, C. J. 2008. Research In Psychology. 5th ed. United States of America: John Wiley \& Sons, Inc.

Intan Liyana. 2005. Kriteria Kompetensi Pengajaran Yang Diperlukan Mengikut Persepsi Pensyarah FPPSM, UTM. Universiti Teknologi Malaysia: Tesis Ijazah Sarjana Muda.

Irniwati@ Nur'aliyah Ahmad. 2002. Tinjauan Terhadap Pengajaran dan Pembelajaran di Kalangan Pensyarah Program Pengajian Separuh Masa Di Bawah Kendalian S.P.A.C.E UTM. Universiti Teknologi Malaysia : Tesis Sarjana Muda.

Janet Ho Siew Ching. 2006. The Validity of The Big Five Inventory and Gender Differences In Students' personality Profile. Universiti Teknologi Malaysia: A Master Thesis.

Johari Sihes \& Zaitun Siden. 2007. Konsepsi Pengajaran Pensyarah dan Hubungannya Dengan Persekitaran Pengajaran Pensyarah. Simposium Pengajaran dan Pembelajaran UTM 2007. 28-29 November 2007. New York Hotel, Johor Bahru.

John Atong. 2002. Penilaian Pelajar Terhadap Pengajaran Pensyarah di Bawah Program S.P.A.C.E di Universiti Teknologi Malaysia, Skudai. Universiti Teknologi Malaysia: Tesis Sarjana Muda.

John, O. P., Srivastava, S. 1999. The Big Five Trait Taxonomy: History, Measurement, and Theoritical Perspectives. Handbook of Personality: Theory \& Research. New York : Guilford Press. 102-138.

Khairul Anwar Mastor, Putai Jin, \& Martin Cooper. 2000. Malay Culture and Personality: A Big Five Perspective. American Behavioral Scientist 44: 95.

Marzuki Ngah. 2005. Persepsi Pelajar-Pelajar KPLI Maktab Perguruan Kuala Terengganu Terhadap Personaliti Pensyarah Maktab. Maktab Perguruan Kuala Terengganu: Tesis Ijazah Sarjana Muda.

Ma'rof Redzuan \& Haslinda Abdullah. 2004. Psikologi. 2nd ed. Universiti Putra Malaysia: McGraw Hill

Mcadams, D. P. 2006. The Person: A New Introduction To Personality Psychology. 4th ed. New York: John Wiley \& Sons. Inc.

McCrae, R. R. \& Costa, P. T. 1985. The NEO Personality Inventory Manual. Odessa, FL: Psychological Assessment Resources.

McCrae, R. R., \& Costa, P. T. 1997. Personality Trait Structure As A Human Universal. American Psychologist. 52(5): 509-516.

Mohd Shakirurahman. 2005. Hubungan Gaya Kepimpinan Pensyarah Dengan Prestasi Pencapaian Pelajar Teknikal di KUiTTHO. Kolej Universiti Teknologi Tun Hussein Onn: Tesis Ijazah Sarjana Muda.

Norhasni Zainal Abidin. 2007. Kerjaya Sebagai Pensyarah. Serdang, Selangor: PTS Profesional.

Norliza Abu@ Awang. 2004. Tinjauan Ke Atas Ciri-Ciri Personaliti Pensyarah Dalam Bidang Teknik Dan Vokasional Yang Mempengaruhi Proses Pengajaran. Universiti Tun Hussein Onn Malaysia: Tesis Sarjana Muda.

Nurhayati Ishak. 2006. Peningkatan Kualiti Pengajaran di Institusi Pengajian Tinggi di Acheh. Universiti Malaya: Tesis Sarjana.

Nurul Hafiz Bin Mohd Zainol. 2007. Hubungan Ciri Personaliti Dengan Gaya Pengajaran Guru Pelatih Tahun Tiga, Aliran Teknik dan Kejuruteraan, Fakulti Pendidikan, Universiti Teknologi Malaysia: Tesis Sarjana Muda

Perlman and McCann. 1998. Student Pet Peeves About Teaching. Experimental Psychology. 8th ed. Belmont, CA: Thomsons Learning. Inc.

Pervin, L. A., \& John. O. P. 2001. Personality Theory and Research. 8th ed. New York: Wiley. 
Polisi dan Kod Amalan Pengajaran dan Pembelajaran Program Diploma dan Ijazah Sarjana Muda. 2007. Skudai: Universiti Teknologi Malaysia.

Ruediger, W. C. 1932. Teaching Procedures. Boston: Houghton Mifflin.

Salimah Mohammad Ali. 2002. Kajian Kes Persepsi Pelajar Terhadap Pengajaran Pensyarah di Jabatan Ilmu Pendidikan Maktab Perguruan Teknik, Kuala Lumpur.

Schinka, J. A., Curtiss, G., Keiffer, K. M. 2007. Journal of Counseling Psychology. 51(2): 168-177. Washington, DC: American Psychological Association.

Schultz, D. P., \& Schultz, S. E. 2005. Theories of Personality. 8th ed. United States of America: Thomson Learning, Inc.

Shahabuddin Hashim. 2002. Teori Personaliti Dari Perspektif Islam, Timur dan Barat. Bentong, Pahang: PTS Publications and Distributors Sdn. Bhd.

Shahril Asan Barseni. 2002. Satu Kajian Kes Mengenai Hubungan Pendekatan Pengajaran Yang Digunakan Oleh Guru-Guru Teknikal Dengan Personaliti Yang Mereka Miliki Di Sekolah Menengah Teknik Dato' Sri Mohd Zin, Alor Gajah, Melaka. Universiti Teknologi Malaysia: Tesis Ijazah Sarjana Muda.

Siti Khamariyah Kamarudin. 2007. Personaliti Dan Intelektual Pensyarah: Persepsi Pelajar Tahun 1 Dan Tahun 4 Fakulti Pendidikan, Universit Teknologi Malaysia. Universiti Teknologi Malaysia: Tesis Sarjana Muda.
Siti Khairun Nisa Aman. 2008. Perlaksanaan Kemahiran Generik Dalam Kalangan Pensyarah Fakulti Pendidikan, Universiti Teknologi Malaysia. Universiti Teknologi Malaysia: Tesis Sarjana Muda.

Syarina Azura Nong Chik. 2008. Penilaian Pengajaran Pensyarah Program Kemahiran Hidup, Fakulti Pendidikan Berdasarkan Persepsi Pelajar 4 SPH (Perdana). Universiti Teknologi Malaysia: Tesis Sarjana Muda.

Tan Sri Prof Dr. Mohd. Zulkifli Mohd. Ghazali. 2007. Mendepani Cabaran Ke Arah Universiti Bertaraf Dunia. Skudai, Johor: Penerbit Universiti Teknologi Malaysia.

Toh, W. S. 2003. Student Centered Pedagogy: Lest We Forget. Muat turun pada 27 Ogos 2008 . http//219.93.129.238/mpblweb/research/2003 toh.htm

Zaini Ujang. 2010. Berpaksi Inovasi Mengangkasa Universiti Menjana Nilai Tinggi. Universiti Teknologi Malaysia.

(2001, April 3). Pelan Induk Pembangunan Pendidikan 2006-2010. Berita Harian.

(2001, Februari 26). Budaya Universiti Di Universiti - Oleh Dr. Sulaiman Masri. Utusan Melayu.

(2009, Februari 28). 4000 Jawatan Pensyarah di IPTA. Utusan Malaysia. 